\title{
Testing a two-scale focused conservation strategy for reducing phosphorus and sediment loads from agricultural watersheds
}

\author{
R. Carvin, L.W. Good, F. Fitzpatrick, C. Diehl, K. Songer, K.J. Meyer, J.C. Panuska, S. Richter, and \\ K. Whalley
}

\begin{abstract}
This study tested a focused strategy for reducing phosphorus $(\mathrm{P})$ and sediment loads in agricultural streams. The strategy involved selecting small watersheds identified as likely to respond relatively quickly, and then focusing conservation practices on high-contributing fields within those watersheds. Two 5,000 ha $(12,360 \mathrm{ac})$ watersheds in the Driftless Area of south central Wisconsin, previously ranked in the top $6 \%$ of similarly sized Wisconsin watersheds for expected responsiveness to conservation efforts to reduce high $\mathrm{P}$ and sediment loads, were chosen for the study. The stream outlets from both watersheds were monitored from October of 2006 through September of 2016 for streamflow and concentrations of sediment, total P, and, beginning in October of 2009, total dissolved P. Fields and pastures having the highest potential $\mathrm{P}$ delivery to the streams in each watershed were identified using the Wisconsin $\mathrm{P}$ Index (Good et al. 2012). After three years of baseline monitoring (2006 to 2009), farmers implemented both field- and farm-based conservation practices in one watershed (treatment) as a means to reduce sediment and $\mathrm{P}$ inputs to the stream from the highest contributing areas, whereas there were no out-of-the-ordinary conservation efforts in the second watershed (control). Implementation occurred primarily in 2011 and 2012. In the four years following implementation of conservation practices (2013 through 2016), there was a statistically significant reduction in storm-event suspended sediment loads in the treatment watershed compared to the control watershed when the ground was not frozen $(p=0.047)$. While there was an apparent reduction in year-round suspended sediment event loads, it was not statistically significant at the $95 \%$ confidence level $(p=0.15)$. Total P loads were significantly reduced for runoff events $(p<0.01)$ with a median reduction of $50 \%$. Total $\mathrm{P}$ and total dissolved $\mathrm{P}$ concentrations for low-flow conditions were also significantly reduced $(p<0.01)$ compared to the control watershed.This study demonstrated that a strategy that first identifies watersheds likely to respond to conservation efforts and then focuses implementation on relatively high-contributing fields within those watersheds can be successful in reducing stream $\mathrm{P}$ concentrations and loads.
\end{abstract}

Key words: agricultural runoff phosphorus-agricultural watersheds-conservation practices - field-scale phosphorus loss assessment-phosphorus concentration and loadssuspended sediment loads

Focusing nonpoint water-protection efforts on watersheds is a well-established policy in the United States, and systematically focusing on watersheds and on fields within those watersheds that disproportionately contribute sediment and phosphorus ( $P$ ) to surface water may optimize agricultural nonpoint program effectiveness (Diebel et al. 2008). In the United States, agricultural nonpoint source runoff is a major lakes are listed for sediment/total suspended solids (WDNR 2015). To reduce the size of the Gulf of Mexico hypoxic zone, the US Environmental Protection Agency (USEPA) has mandated state efforts to control agricultural nonpoint pollution with a goal of reducing $\mathrm{P}$ and nitrogen $(\mathrm{N})$ inputs from the Mississippi River by 45\% (Mississippi River/ Gulf of Mexico Watershed Nutrient Task Force 2008).

Some nonpoint source reduction projects promoting agricultural conservation practices, often termed "best management practices" or BMPs, have been successful at the field and small watershed scale. For example, in New York State, Bishop et al. (2005) found a $43 \%$ reduction in dissolved $\mathrm{P}$ (DP) and a 29\% reduction in particulate $\mathrm{P}(\mathrm{PP})$ in a 160 ha $(390 \mathrm{ac})$ dairy farm watershed compared to an 86 ha $(210 \mathrm{ac})$ nonfarm watershed following implementation of a wide range of practices including manure storage, barnyard area runoff management, and field practices to curb erosion. Similar success was observed in a comparison of small watersheds $(<210$ ha $[<519$

Rebecca Carvin is a physical scientist at the US Geological Survey (USGS) Wisconsin Water Science Center, Middleton, Wisconsin. Laura W. Good is a senior scientist in the Department of Soil Science, University of Wisconsin, Madison, Wisconsin. Faith Fitzpatrick is a research hydrologist at the USGS Wisconsin Water Science Center, Middleton, Wisconsin. Curt Diehl is a conservation specialist in the Land Conservation Division, Land and Water Resources Department, Dane County, Wisconsin. Katherine Songer was formerly a conservation intern with the Land Conservation Division, Land and Water Resources Department, Dane County, Wiscon$\sin$, and graduate student at the University of Wisconsin, Madison, Wisconsin. She is currently a writer in Portland, Oregon. Kimberly J. Meyer was formerly a conservation intern with the Land Conservation Division, Land and Water Resources Department, Dane County, Wisconsin, and graduate student at the University of Wisconsin, Madison, Wisconsin. She is currently a nutrient management specialist with Madison Metropolitan Sewerage District in Madison, Wisconsin. John C. Panuska is distinguished faculty associate in the Department of Biological Systems Engineering, University of Wisconsin, Madison, Wisconsin. Steve Richter is director of conservation programs for The Nature Conservancy in Madison, Wisconsin. Kyle Whalley is a conservation data management specialist in the Land Conservation Division, Land and Water Resources Department, Dane County, Wisconsin. 
ac]) in Manitoba, Canada, when a suite of recommended land management practices for livestock producers implemented in one of the watersheds resulted in a 38\% total P (TP) reduction ( $\mathrm{Li}$ et al. 2011). At larger watershed scales, however, demonstrating quantifiable reductions has proven difficult (Aschmann 2000; Mulla et al. 2008; Osmond et al. 2012). Using a paired watershed study design, Lemke et al. (2011) failed to find evidence of a decrease in suspended sediment, $\mathrm{TP}$, or nitrate- $\mathrm{N}\left(\mathrm{NO}_{3}^{-}-\mathrm{N}\right)$ with practice changes in a 4,000 ha $(9,880 \mathrm{ac})$ treatment watershed. This resulted in suggestions that projects target high-impact areas, times, and pathways for losses of specific nutrients and quantify expected outcomes of practices prior to implementation (Lemke et al. 2011).

In 2005, a policy report commissioned by the Wisconsin legislature recommended use of a targeted strategy to address agricultural nutrient and sediment losses in Wisconsin (UW-CALS 2005; Diebel et al. 2008). This report was prepared by the Wisconsin Buffer Initiative (WBI), a group composed of university researchers; federal, state, and local agency staff; and representatives of agricultural and environmental stakeholder organizations. Although it was originally charged with creating guidelines for riparian buffers in agricultural landscapes, the WBI's ultimate recommendation was to take a broader, systems approach to implementing agricultural conservation practices, including buffers, to improve water quality (UW-CALS 2005). In this approach, conservation efforts are located to maximize benefits by first selecting watersheds likely to respond to these efforts, and then, within each selected watershed, prioritizing the highest sediment or P loss areas (fields) for implementation (UW-CALS 2005). Diebel et al. (2008) further indicated that optimum water quality program effectiveness can be achieved by beginning with the watershed having highest restoration potential, implementing conservation practices on the highest pollutant loading areas within that watershed, and then moving on to the watershed with the next highest restoration potential. This strategy assumes that, within each watershed, there is a skewed or log-normal distribution of field sediment and $\mathrm{P}$ loss potential with a high-contributing "tail" of areas resulting from the interaction of vulnerable environmental settings and high-loss management behaviors (Nowak et al. 2006).
To aid in watershed selection, the WBI report ranked 1,598 spatially independent Wisconsin watersheds using a model to indicate the likelihood of improving or sustaining stream and later water quality and aquatic biology (UW-CALS 2005). Sizes of WBI watersheds ranged from 20 to 100 $\mathrm{km}^{2}$ (7.7 to $\left.38.6 \mathrm{mi}^{2}\right)$ with a mean of 54 $\mathrm{km}^{2}\left(20.8 \mathrm{mi}^{2}\right)$ and was based on analysis of optimal watershed program configuration (Maxted et al. 2009). Land cover and drainage density were primary drivers in the model to indicate reduction potential for sediment and $\mathrm{P}$ in each watershed (Diebel et al. 2009). The watershed ranking for potential to respond to conservation practices discounted "unbufferable" sediment and P sources in the watershed, including streambank and in-stream sediments, fine-textured sediments and DP, point sources, and urban storm water (UW-CALS 2005; Diebel et al 2009). For most of the WBI watersheds, the model indicated that conservation practices could potentially remove $70 \%$ of the stream sediment and P loads (Diebel et al. 2009).

Following watershed selection, the next challenge is to prioritize areas within the watershed for implementation. To rank agricultural fields by their relative contributions of sediment or $\mathrm{P}$ to the stream, the WBI recommended two assessment tools already in use in Wisconsin for conservation and nutrient management planning: the Revised Universal Soil Loss Equation 2 (RUSLE2) and the Wisconsin Phosphorus Index (WPI) (UW-CALS 2005). RUSLE2 estimates field crop rotation average annual soil erosion in mass (megagrams) per unit area (USDA ARS 2006). The WPI is a model that estimates annual $\mathrm{P}$ delivery from fields to surface water as $\mathrm{PP}$ and $\mathrm{DP}$ in pounds of $\mathrm{P}$ per acre per year. (To avoid confusion for the reader, we note that in its application as an index for rating fields by runoff $\mathrm{P}$ loss potential, the WPI has been reported without units.) Testing with field runoff data demonstrated that the WPI accurately ranks field PP, DP, and TP runoff loads (Good et al. 2012). The WBI recommended upper limits for both erosion and the WPI to match those set for nutrient management planning in Wisconsin (Nutrient Management Standard 590; USDA NRCS 2005). Therefore, the limit on erosion is the USDA Natural Resources Conservation Service (NRCS)-designated soil loss tolerance $(\mathrm{T})$, which varies by soil map unit from 2.24 $\mathrm{Mg} \mathrm{ha}^{-1} \mathrm{y}^{-1}$ to $11.2 \mathrm{Mg}$

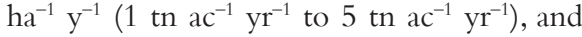
the WPI limit is a rotational average value of 6 . These limits have since been incorporated into Wisconsin agricultural runoff standards (Wis. Stats. NR 151 2010).

The study's objective was to test whether using this proposed watershed-and field-scale prioritization strategy to implement conservation practices could achieve quantifiable reductions in measured stream sediment and $\mathrm{P}$ loads in an agricultural watershed. Specifically, we monitored streams in two watersheds with similar WBI rankings. In one, we implemented a focused conservation strategy, and we used the other as a control.

\section{Materials and Methods}

Watershed Selection and Description. To test the WBI strategy, we needed to work in a watershed that was identified as likely to respond to conservation efforts. To use a paired watershed approach, we needed two similar watersheds geographically near enough to each other to experience similar storm events. We selected two 5,000 ha $(12,000 \mathrm{ac})$ watersheds located approximately $12 \mathrm{~km}(7.5 \mathrm{mi})$ apart to serve as a treatment and control. These watersheds were within the top $6 \%$ in the WBI ranking for potential response to sediment and nutrient reduction practices (UW-CALS 2005).

The study watersheds are groundwater-fed branches of the Pecatonica River (figure $1)$. Both are primarily agricultural watersheds, with a mixture of dairy, beef, and cash grain farms including cropland, pastures, woodlands, and grasslands. Proportions of cropland and woodlands in each watershed were similar at the start of the implementation; however, the treatment watershed had less pasture and pastured woodland than the control (11\% versus $17 \%)$, as well as more grassland (28\% versus $24 \%$ ) (table 1 ). Cropland and pastures in both watersheds are on silt loam soils and can be steeply sloped (up to 16\%). A detailed description of the treatment watershed topography, soils, and stream morphology is contained in Lamba et al. (2015a).

Agricultural Field Management Inventory and Assessment. Dane County Land Conservation Division (LCD) staff inventoried agricultural land management in both watersheds during the 2007 to 2009 baseline period. They asked farmers about their field management practices, including current crop rotations, expected crop yields, 
tillage operations, fertilizer and manure application rates on each field, number and type of livestock, amount of manure collected from barns and barnyards and spread on cropland, and amount of time animals spent on pastures or uncovered lots. Field and pasture soils were sampled using the recommended agronomic sampling procedures for Wisconsin at a maximum density of one sample per 2.1 ha $(5 \mathrm{ac})$ and analyzed for Bray P1 soil test P (STP) and organic matter percentage (Laboski and Peters 2012). Treatment watershed inventory was part of the WBI strategy to identify areas with high runoff $\mathrm{P}$ loss and/or erosion potential. The purpose of the control watershed inventory was to document the estimated P loss and erosion distribution and compare it to that of the treatment watershed.

Field-Scale Assessment Tools. Using the crop rotations in place during the crop years 2007 through 2009, we calculated RUSLE2 erosion and WPI values for all fields and pastures on inventoried farms. Inventory information for both watersheds was entered into the Soil Nutrient Application Planner Plus model (SnapPlus, version 1.32; Kaarakka et al. 2011), which includes both the RUSLE2 and WPI models. We used USDA NRCS planning guidelines to select which of the soils mapped in a field to use in calculating field soil erosion rates. These guidelines are designed to ensure the most erodible part of the field is protected, so the soil map units selected for calculating soil erosion estimates represent the "dominant critical slope" rather than the predominant soil map unit in the field (USDA NRCS Wisconsin 2005). Sediment delivery from RUSLE2 for this designated slope was used in the WPI PP load equations (Good et al. 2012).

Implementing Field-Scale Conservation Practices. Dane County LCD consulted with farmers and offered incentive payments to implement field-scale management changes on a farm-by-farm basis. Within the treatment watershed, they used the inventory and WPI modeling results to identify fields and pastures with critical areas having a high runoff $\mathrm{P}$ loss potential. Fields with WPI greater than 6 were given highest priority for incentives for practices. The second highest ranking was given to those with WPI values between 3 and 6 .

Dane County LCD contacted and met one-on-one with farmers to discuss a variety of practices designed to reduce erosion and/

\section{Figure 1}

Location of paired watersheds in southwest Wisconsin's Driftless (unglaciated) region.

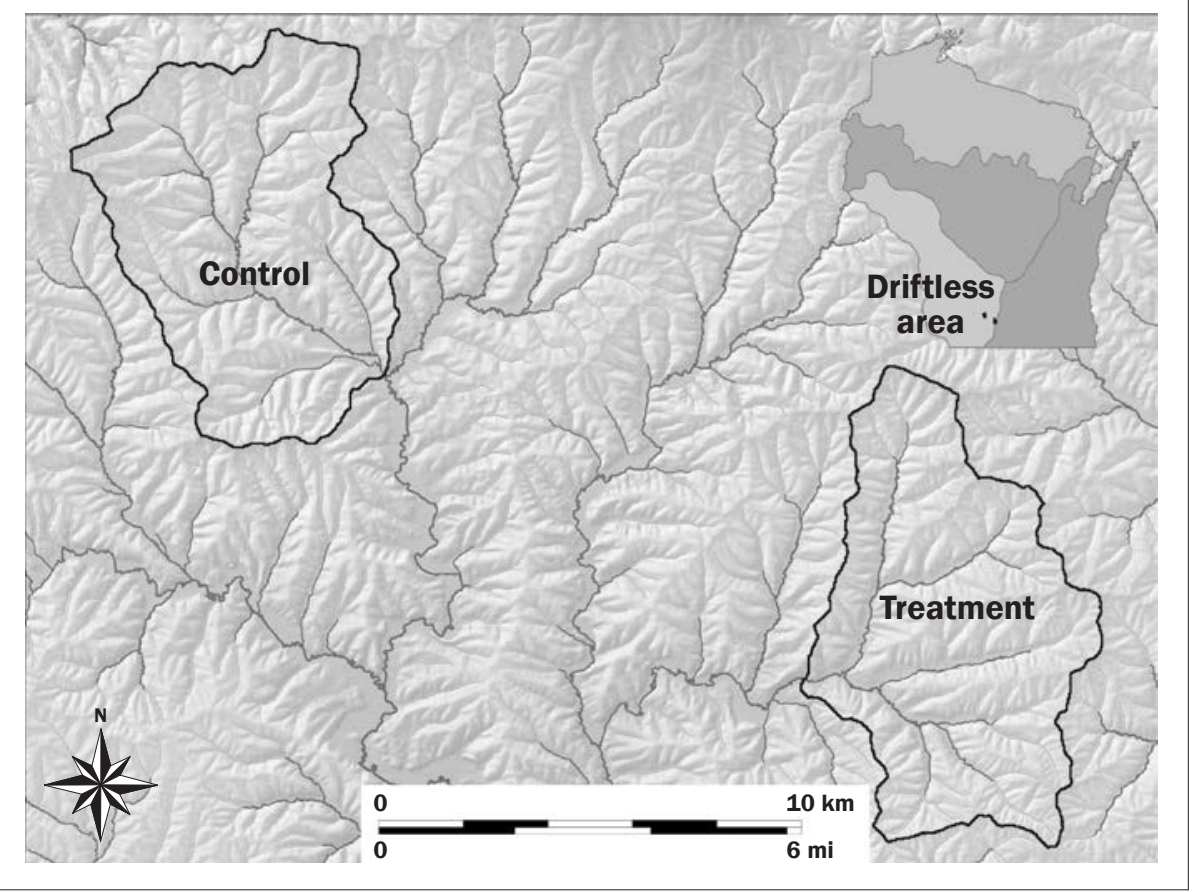

Table 1

Land use in treatment and control watersheds prior to 2011 implementation.

\begin{tabular}{lccccc}
\hline & \multicolumn{2}{l}{ Treatment } & & Control & \\
\cline { 2 - 3 } Land use & Area (ha) & Watershed (\%) & & Area (ha) & Watershed (\%) \\
\hline Cropland & 1,686 & 34 & 1,650 & 34 \\
Pasture & 386 & 8 & 553 & 11 \\
Pastured woodlands & 158 & 3 & 272 & 6 \\
Grasslands & 1,376 & 28 & 1,161 & 24 \\
Woodlands & 1,076 & 22 & & 1,039 & 21 \\
Other & 295 & 6 & 249 & 5 \\
Total & 4,977 & 100 & & &
\end{tabular}

or P losses. They began with farmers who had the highest estimate of aggregate runoff $\mathrm{P}$ loads. Twelve farmers with WPI values greater than 6 and three farmers with values between 3 and 6 participated in the project, representing about a third of the farmers active in the watershed. Participating farmers chose practices that best suited their long-term operations. Prior to implementation of field practices, Dane County LCD recalculated the WPI using the selected practice to determine if it had the potential to reduce the post-implementation WPI to below the target value.

Implementation began slowly in 2010 with 79 ha $(190 \mathrm{ac})$ of row crops going into no-tillage management. However, by the end of the 2011 season, field management prac- tices, primarily no-tillage on row crops, were in place on 623 ha $(1,540 \mathrm{ac})$. Those fields, plus an additional 434 ha $(1,070 \mathrm{ac})$, were under nutrient management plans. Dane County also supplemented the field management practices with incentive payments for fencing, stream crossings (to limit cattle access to streams), and other practices to allow continuous vegetative cover and to stabilize eroding banks in high-WPI riparian pasture areas adjacent to streams. In addition, eight barnyard runoff reduction projects adjacent to streams and three small grade stabilization structures down-gradient of high WPI areas were completed in 2012, along with $1.6 \mathrm{~km}$ (1 mi) of eroding bank reshaping and stream bank stabilization. 
Modeling Erosion and Phosphorus Reductions. During the project, we tracked field and pasture management on participating farms in the treatment watershed, updating the erosion and WPI calculations to reflect observed management changes. In 2016, Dane County LCD re-interviewed farmers in the treatment watershed to obtain updated information on their cropped field management. Erosion and WPI values were recalculated for inventoried fields to directly compare pre-implementation 2007 to 2010 averages to those post-implementation 2013 to 2016 averages (SnapPlus v.16; Wolter et al. 2016). Phosphorus-to-the-stream reductions were also modeled for the barnyard improvements and for restricting cattle access in the stream. The Wisconsin Barnyard Runoff Model (BARNY) (WDNR 1996) was applied to estimate barnyard runoff $\mathrm{P}$ loads before and after reconstruction. Runoff $\mathrm{P}$ losses from grazing cattle feces deposited on land adjacent to the stream are accounted for in the pasture's WPI, but feces deposited in the stream are not. Based on James et al. (2007), we also estimated direct fecal deposition in the treatment watershed stream as $5 \%$ of total daily feces from cattle with direct access to streams. We calculated reductions in delivery from pasture fencing and stream crossings by estimating the reduction in total animal access to the stream.

Water Quality Monitoring. The US Geological Survey (USGS) installed streamflow-gaging and water quality monitoring stations at the outlet of the treatment watershed, Pleasant Valley Creek (USGS station 05432927), and the control watershed, Ridgeway Branch (USGS station 05432695). USGS personnel used standard stream gaging techniques to record streamflow (Rantz et al. 1982) and standard USGS water-sampling techniques to collect discrete water samples at both stations (USGS 2006). A stage-activated refrigerated water sampler automatically collected water samples representing high flow at each gaging station and chilled samples to $4^{\circ} \mathrm{C}\left(39.2^{\circ} \mathrm{F}\right)$ after collection. We selected samples for analysis to represent variation in water quality over a range of increasing and decreasing stages. Low-flow sample collection took place every two weeks from March through November and monthly from December through February. Both streams are groundwater fed and do not freeze for the majority of winter, and heated sample lines at each site prevented the lines from freezing. Thus, we collected year-round water samples during low-flow periods, rain-on-snow, snowmelt, and rain events.

Samples collected from the gaging stations were chilled on ice in coolers, processed at the USGS field office, and then transported to the Wisconsin State Laboratory of Hygiene (WSLH) to be analyzed for total suspended sediment (SS), P, and total dissolved P (TDP) (WSLH 1993). We collected streamflow, SS, and TP samples from October of 2006 through September of 2016. We did not collect TDP samples during events until October of 2009. Prior to that, we collected TDP samples only during low-flow conditions from October of 2006 through September of 2009, at which point we added TDP samples to the event sample analysis. Particulate $\mathrm{P}$ is defined as the portion of TP bound to sediment and is calculated as the difference between TP and TDP.

We calculated daily mean concentrations and daily mean loads for SS and TP using the Graphical Constituent Loading Analysis System (GCLAS) (Koltun et al. 2006). Using the integration method, we computed event loads with multiple discrete samples and continuous streamflow data (Porterfield 1972; Corsi et al. 2005; Carvin 2018). Sample concentrations, daily mean concentrations, and daily mean loads are available to the public through the National Water Information System (NWIS; USGS 2016).

We used the USGS Hydrograph Separation Program (HYSEP; Sloto and Crouse 1996), which separates daily mean streamflow and loading data into baseflow and stormflow components following the method described in Danz et al. (2010). Baseflow is the part of streamflow attributed to groundwater discharge into a stream without surface runoff (Stuckey 2006). The data for portions of TP, TDP, SS daily loads, and daily mean streamflow attributed to baseflow are available online (Carvin 2018).

Statistical Evaluation of Paired Data. We evaluated the effectiveness of conservation efforts implemented in the treatment watershed with a paired watershed study design based on differences in SS and P loads. This study design quantified the relation between paired watersheds to determine if they respond in a predictable manner together, and assumed the relation remained the same over time except for the influence of focused conservation efforts in the treatment watershed during the post-implementation period (Selbig 2016). It did not assume that the control and test watersheds were statistically the same.

Following procedures outlined by Clausen and Spooner (1993), we analyzed paired water quality data measured during the baseline and post-implementation periods to determine if conservation was effective. We confirmed the significance of the relation between log-transformed paired water quality data during each period using analysis of variance (ANOVA, $\alpha=0.05$ ). At the end of the post-implementation period, we determined the significance of the effect of conservation using analysis of covariance (ANCOVA) (Clausen and Spooner 1993). The analysis is a series of steps determining the significance of the post-implementation regression; the significance of the overall regression, which combines the baseline and post-implementation phase data; the difference between the slopes of the baseline and post-implementation regressions; and the difference between the intercepts of the baseline and post-implementation regressions. A change in intercepts but not slopes between the baseline and post-implementation phase indicates an overall parallel shift in the regression equation. If the post-implementation regression shifted below that of the baseline phase, we can consider the form of treatment (in this case conservation practices) effective at reducing nutrient loads. No significant change in either the slope or intercept of the post-implementation regression suggests conservation had little to no effect on nutrient loads when compared to the baseline period. If the results of the ANCOVA test for slope and/or intercept reveal a significant difference between the baseline and post-implementation regressions, the regression equation representing the baseline period can be used to quantify the degree of load reduction as a result of conservation. To do this we predicted what average runoff event loads should have been in the test watershed during the post-implementation phase if there had not been conservation. We express the overall reduction due to conservation as a percentage change based on the average predicted and observed values during the post-implementation phase (Clausen and Spooner 1993).

Our paired analysis used event loads and low-flow sample concentration values from the treatment and control watersheds. Paired sample data included 111 event loads: 52 
events during baseline (October of 2006 through September of 2010), and 59 events during post-implementation (October of 2012 through September of 2016; table 2). Since very little implementation occurred in 2010, we included 2010 data in the baseline period in order to expand the range of measured event loads. To allow time for implemented practices to influence water quality, we did not include the implementation period (October of 2010 through September of 2012) in the analysis. We also subcategorized event loads by frozen and unfrozen soil conditions to determine if implementation was more effective during different conditions.

\section{Results and Discussion}

Pre-Implementation Erosion and Runoff Phosphorus Inventory. Inventories with soil samples and erosion and WPI calculations were completed for $87 \%$ of the agricultural land (cropland + pasture) in the treatment watershed and $63 \%$ in the control watershed. Crop rotations were similar in both watersheds, reflecting the type of farming operations. Dairy and beef operation crop rotations ranged up to eight years with row crops, primarily corn (Zea mays L.), wheat (Triticum aestivum L.), or soybeans (Glycine $\max$ L.) alternating with three or more years in a perennial hay crop, usually alfalfa (Medicago sativa L.). Livestock operations often had continuous corn, harvested as grain or silage, on flatter ground. Cash grain rotations were primarily corn and soybean and occasionally included wheat. No manure storage is located in either watershed, so manure from livestock operations is spread year-round, even on frozen soils. Animal unit (defined as $454 \mathrm{~kg}$ [1,000 lb] of beef or dairy cow, sheep, llama, goat, or bison) density on agricultural land in both watersheds was 0.9 $\mathrm{ha}^{-1}\left(0.4 \mathrm{ac}^{-1}\right)$. Mean slope used for calculating erosion for the dominant critical soil for fields in both the treatment and control watersheds was $11 \%$. Due to the steepness of the terrain, field sizes are small, with a mean of 1.9 ha $(4.7 \mathrm{ac})$. Many fields are farmed on the contour or are in a contour-strip system.

The treatment and control watersheds had similar means and ranges of STP, RUSLE2 erosion, and WPI values (table 3 ). In addition, the distribution of WPI values across inventoried watershed area had similar log-normal patterns (figure 2). For the treatment watershed, the mean rotational WPI was 3.4, with

\section{Table 2}

Suspended sediment (SS) and total phosphorus (TP) event load summary for the treatment and control watersheds during the baseline period (October of 2006 to September of 2010) and the post-implementation period (October of 2012 to September of 2016).

\begin{tabular}{|c|c|c|c|c|c|c|}
\hline \multirow[b]{2}{*}{ Watershed } & \multicolumn{3}{|c|}{ Baseline $(n=52)$} & \multicolumn{3}{|c|}{ Post-implementation $(n=59)$} \\
\hline & Min & Mean & Max & Min & Mean & Max \\
\hline \multicolumn{7}{|l|}{ Treatment } \\
\hline SS (Mg) & 2.3 & 59 & 330 & 0.2 & 34 & 790 \\
\hline $\mathrm{TP}(\mathrm{kg})$ & 9.6 & 140 & 630 & 1.3 & 55 & 540 \\
\hline \multicolumn{7}{|l|}{ Control } \\
\hline SS (Mg) & 0.1 & 68 & 910 & 0.2 & 64 & 1,200 \\
\hline $\mathrm{TP}(\mathrm{kg})$ & 3.7 & 120 & 1,000 & 1.2 & 75 & 680 \\
\hline
\end{tabular}

values ranging from 0.1 to 95 . Of the inventoried treatment watershed agricultural land, $69 \%$ had a WPI of 3 or less, and $21 \%$ was between 3 and 6 (table 4). Only 10\% had WPI values exceeding 6 ; however, these areas contributed more than a third of the total estimated losses. Fields and pastures with higher WPI values generally had relatively high erosion rates and/or high STP concentrations (examples shown in figure 3). Additionally, some high-animal-density pasture areas had high WPI values due to estimated DP runoff losses from surface deposition of fecal P. Many of the high-contributing pasture areas were adjacent to a stream.

RUSLE2 erosion rates averaged $4.3 \mathrm{Mg}$ $\mathrm{ha}^{-1} \mathrm{y}^{-1}$ (1.9 tn $\left.\mathrm{ac}^{-1} \mathrm{yr}^{-1}\right)$, ranging from $<0.1$ to $52 \mathrm{Mg} \mathrm{ha}^{-1} \mathrm{y}^{-1}\left(<0.1\right.$ to $23 \mathrm{tn} \mathrm{ac}^{-1}$ $\left.\mathrm{yr}^{-1}\right)$. Estimated soil loss exceeded $\mathrm{T}$ for the dominant critical soil on 440 ha $(1,090 \mathrm{ac})$. Although the WPI rather than RUSLE2 soil loss was used as the primary assessment for prioritizing fields for conservation practices, it should be noted that fields with higher soil loss (>6.7 $\mathrm{Mg} \mathrm{ha}^{-1} \mathrm{y}^{-1}\left[3 \mathrm{tn} \mathrm{ac}^{-1}\right.$ $\mathrm{yr}^{-1}$ ]) were a subset of the fields with WPI greater than 3 .
Estimated Erosion and Runoff Phosphorus Reductions. Most of the farms with highWPI fields agreed to participate in the project. Overall, farmers operating 63\% of the land area with WPI $>6$ and $66 \%$ of the area with WPI 3 to 6 were included in the project. In a deviation from the original WBI focused implementation strategy, participating farmers converted from tillage to no-tillage on row crops across most or all of their fields, including those with WPI below 3. The more widespread implementation was adopted for ease of farm operations. Overall, 1,060 ha $(2,610 \mathrm{ac})$, or close to half of the agricultural land in the watershed, was originally under contract for incentive payments, although land ownership/operator changes resulted in some attrition (approximately 10\%).

The 2016 cropland inventory found most of the land originally under contract for no-tillage was still in no-tillage in 2016, and participating farmers were continuing to follow nutrient management practices. Comparing the conditions prior to implementation with those in 2013 to 2016, we estimated a $57 \%$ reduction in RUSLE2 ero-

\section{Table 3}

Area-weighted mean and ranges for agricultural (cropland and pasture) land inventory results for treatment and control watersheds for crop rotations in place from 2007 to 2009 .

\begin{tabular}{lcccl}
\hline & Treatment & \multicolumn{3}{c}{ Control } \\
\cline { 2 - 5 } Inventoried area (ha) & 1,796 & \multicolumn{2}{c}{1,470} & \\
Inventoried fields/pastures $(n)$ & 969 & & 658 & \\
\hline & Mean & Range & Mean & Range \\
\cline { 2 - 5 } Soil test P (Bray P1) $\left(\mathrm{mg} \mathrm{kg}^{-1}\right)$ & 41.0 & 3 to 383 & 37.0 & 4 to 247 \\
RUSLE2 rotation erosion rate $\left(\mathrm{Mg} \mathrm{ha}^{-1} \mathrm{y}^{-1}\right)$ & 4.3 & $<0.1$ to 52 & 5.4 & $<0.1$ to 34 \\
Rotation WPI* & 3.4 & $<0.1$ to 95 & 3.6 & 0.3 to 20 \\
\hline
\end{tabular}

*WPI = Wisconsin Phosphorus Index, a unitless index that is calculated as an estimate of average field to stream phosphorus delivery in $\mathrm{Ib} \mathrm{ac}^{-1} \mathrm{yr}^{-1}$. 


\section{Figure 2}

Distribution of Wisconsin Phosphorus Index (WPI) values for (a) treatment and (b) control watershed.

$$
\text { (a) }
$$

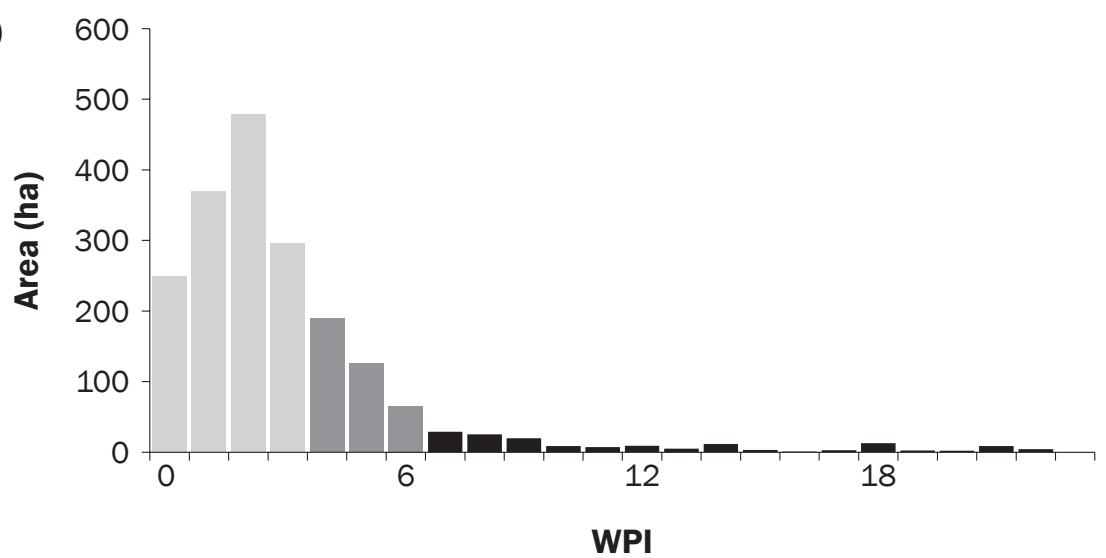

(b)

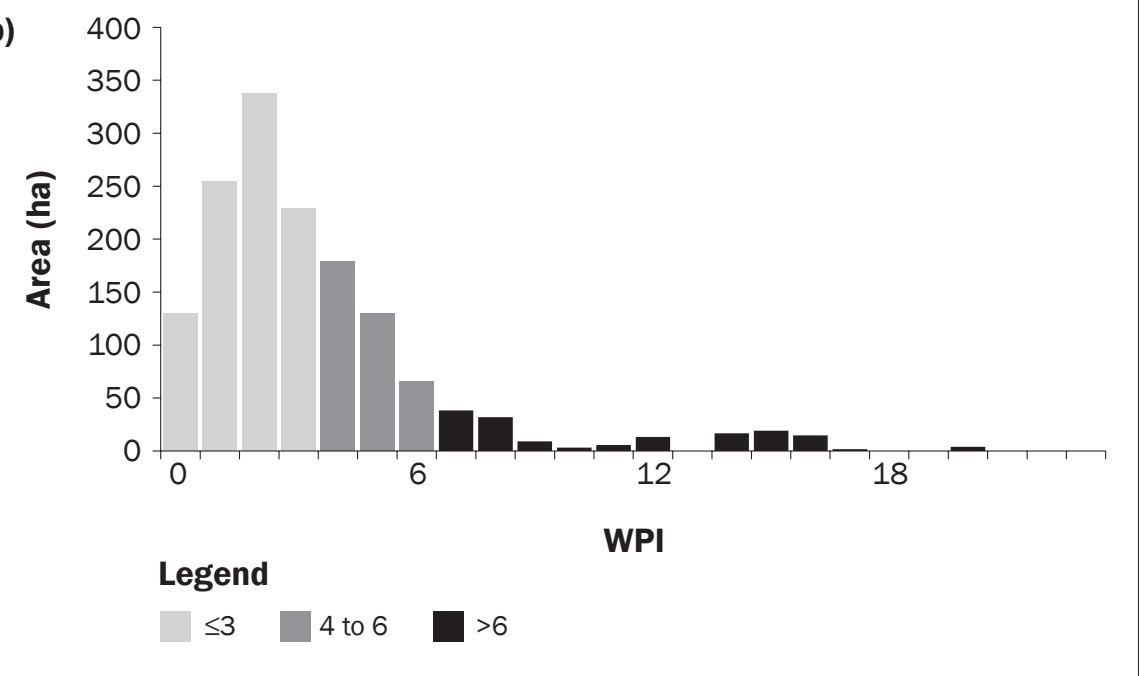

Table 4

Baseline rotational average Wisconsin Phosphorus Index (WPI) distribution for inventoried treatment watershed agricultural land.

\begin{tabular}{|c|c|c|c|c|c|c|}
\hline \multirow[b]{2}{*}{ WPI category } & \multicolumn{2}{|l|}{ Area } & \multicolumn{2}{|c|}{ WPI load* } & \multicolumn{2}{|c|}{$\begin{array}{l}\text { WPI load change } \\
\text { if all reduced below } \\
\text { categoryt }\end{array}$} \\
\hline & ha & $\%$ of total & $n$ & $\%$ of total & $n$ & $\%$ of total \\
\hline$\leq 3$ & 1,234 & 69 & 5,480 & 34 & $-16,200$ & -100 \\
\hline 4 to 6 & 380 & 21 & 4,400 & 27 & $-6,600$ & -41 \\
\hline$>6$ & 182 & 10 & 6,430 & 39 & $-3,700$ & -23 \\
\hline
\end{tabular}

*Sum of WPI $\times$ area for all agricultural land in this category.

†WPI load reduction if all agricultural land in this and higher categories was managed to have the maximum WPI value for the next lowest category.

sion and a 59\% reduction in WPI P delivery resulting from project implementation on cropland, and similar reductions of $64 \%$ and $71 \%$ on pastures (table 5 ). The close correspondence between estimated reductions in erosion and $\mathrm{P}$ delivery reflect that the major- ity of the WPI-estimated P delivery in this watershed is via eroding sediment. Particulate $\mathrm{P}$ made up $77 \%$ of the WPI.

The 2016 reinventory of the cropland also showed that land management of fields and farms not under contract was dynamic.
Management shifts after owner and/or operator changes resulted in higher WPI values for some fields in 2016 than the original inventory. The conversion of Conservation Reserve Program (CRP) grasslands to row crops resulted in a net increase in cropland of almost $20 \%$ (340 ha [840 ac]) from 2006 to 2013. Tillage on much of the newly cropped land led to greatly increased estimated erosion and $\mathrm{P}$ delivery. In contrast, another trend reduced the distribution of high $\mathrm{P}$ loss pastures and lots. A reduction in small dairy herds (milking $<100$ cows) resulted in less heavy use of pastures and lots near streams. Some dairy herds were replaced by beef, but total animal units in the treatment watershed declined by $34 \%$ over the period from 2007 to 2016. For all inventoried agricultural land, including that not under contract, estimated reductions from project implementation were $15 \%$ for erosion and $18 \%$ for $\mathrm{P}$ delivery (table 5).

Substantial reductions of $\mathrm{P}$ also came from nonfield practices. Estimated annual P loss reductions resulting from barnyard improvements were $260 \mathrm{~kg} \mathrm{P} \mathrm{y}^{-1}\left(573.2 \mathrm{lb} \mathrm{P} \mathrm{yr}^{-1}\right)$ as estimated by BARNY. Barnyards were not included in the original inventory because they were not part of the WBI strategy. Thus, a pre- and post-implementation comparison for all barnyards in the watershed was not possible. The pre- and post-implementation comparison for the reconstructed barnyards showed 95\% reduction in runoff $\mathrm{P}$ losses. In 2007 , annual deposition of fecal P from cattle in the stream was estimated at $261 \mathrm{~kg}(575.4$ $\mathrm{lb})$; in 2016 it was $43 \mathrm{~kg}$ (94.8 lb), an estimated $83 \%$ reduction. The majority of this reduction $(>80 \%)$ can be attributed to project implementation of fencing and stream crossings; the remaining reduction was a result of the overall decline in the number of animals in the watershed.

The project used the modeled estimates of proportionate reductions in erosion and runoff $\mathrm{P}$ to ascertain that enough conservation practices had been implemented that we might expect a measureable effect at the watershed outlet. We caution against direct comparison of magnitude of modeled loads from the different $\mathrm{P}$ loss models because they may not be equivalent. In particular, the WPI is designed for use in a nutrient management conservation planning framework that errs toward overestimating average $\mathrm{P}$ delivery. The overestimation is from a combination of the use of the dominant critical soil type and a very basic field-to-stream delivery routine. 


\section{Figure 3}

Examples of representative high phosphorus $(P)$ loss areas in the treatment watershed and the proportion of Wisconsin $\mathrm{P}$ Index (WPI) estimated runoff $\mathrm{P}$ losses contributed by dissolved $\mathrm{P}$ from manure and soil and by particulates for the original managements and lower $P$ loss management alternatives. (a) Original management: three-year corn silage and three-year alfalfa; spring chisel plowed on contour. Alternative management: corn silage-corn grain-corn silage and three-year alfalfa; no-till corn and spring chisel plow alfalfa seeding. (b) Original management: two dairy cows per acre year-round ( $75 \%$ of day). Alternative management: fewer than one dairy cow per acre; pasture managed to maintain grass cover.

(a)

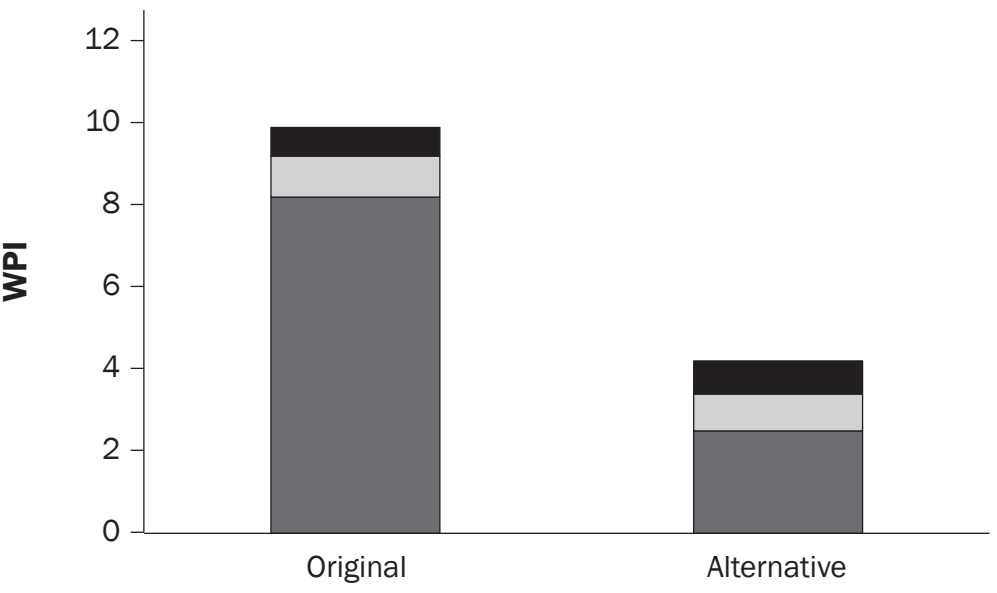

(b)

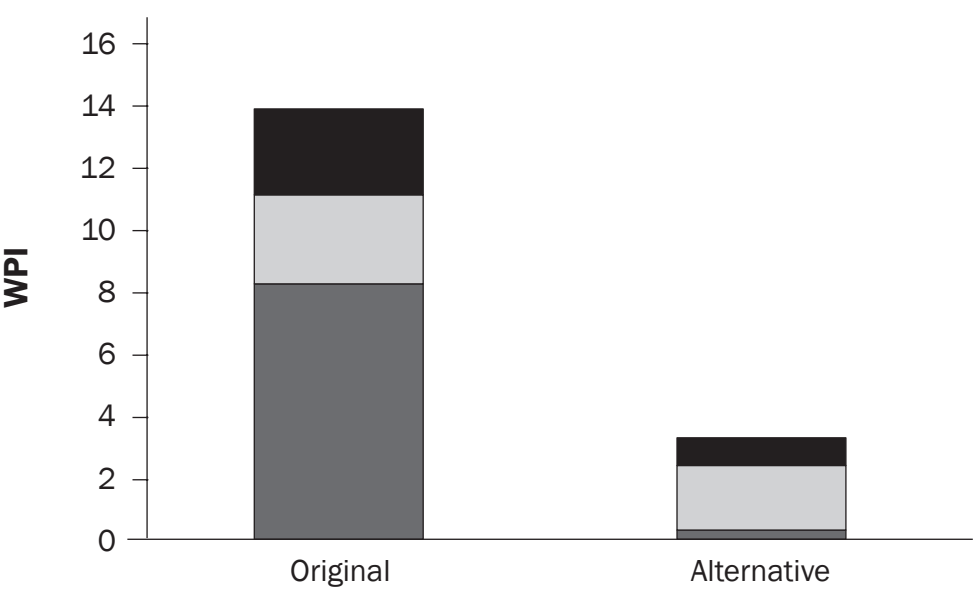

Legend

Particulate P $\square$ Dissolved P from soil

Dissolved $\mathrm{P}$ from manure

In contrast, BARNY has no delivery routine; it represents runoff from the yard or lot itself, not what enters the stream. Furthermore, estimated reductions from stream fencing represent direct reductions in stream inputs assuming $100 \%$ delivery from animals defecating in the stream. Additionally, WPI and BARNY results are not likely to correspond to actual reduction at the watershed outlet in any given year because of natural hydrologic variations from year to year.

\section{Streamflow and Water Quality} Characteristics. Annual variation in streamflow, SS, and TP loads in both the treatment and control watersheds roughly corresponded to variations in annual rainfall (figure 4a). The treatment watershed had annual SS loads less than or similar to the control in three of four baseline years. In the post-implementation period, annual SS loads in the treatment watershed were less than the control in three of four years to a larger degree than in the baseline period (figure $4 \mathrm{~b}$ ). The treatment watershed had consistently higher annual TP loads than the control in the baseline period. In the post-implementation period, annual TP loads in the treatment watershed were lower than the control watershed in two of four years (figure $4 \mathrm{c}$ ).

The designs for most conservation practices implemented in this project reduce the movement of $\mathrm{P}$ and sediment delivery via runoff and may therefore have a greater influence on event loads than on baseflow loads. Hydrograph separation describes the distribution of stormflow and baseflow in annual streamflow, SS, and TP loads (figure $4 \mathrm{~b}$ and $4 \mathrm{c}$ ). Stormflow contributed $10 \%$ of total streamflow from October of 2006 to September of 2016 in the treatment and 15\% in the control watershed, respectively, yet it contributed more than $50 \%$ of annual SS and TP loads. This concurs with the findings in Danz et al. (2010) that baseflow contributed most of the annual streamflow, while most of the annual SS and TP loads were transported in stormflow for eight Driftless Area streams with agricultural watersheds ranging from 14 to $119 \mathrm{~km}^{2}$ (5 to $42 \mathrm{mi}^{2}$ ).

Sediment fingerprinting studies of streambed and SS samples in the treatment watershed ran concurrently with this project (Lamba et al. 2015a). The findings demonstrate the appropriateness of focusing on agricultural land conservation practices to reduce in-stream sediment loads in this watershed. While streambank erosion is the primary source of SS transported in some streams in Wisconsin and elsewhere (Fitzpatrick et al. 1999; Neal and Anders 2015; Gellis et al. 2015), the dominant source of SS measured at the treatment watershed outlet was from cropland and pastures (Lamba et al. 2015b). There was a positive linear relation between the proportion of the fine sediment coming from agricultural lands and the proportion of the subwatershed that was agricultural (Lamba et al. 2015a).

Pre-Implementation Stream Sediment and Phosphorus. There was a significant correlation in streamflow, SS, and P event loads, and low-flow concentrations between the treatment and control watersheds during the pre-implementation period $(p<0.01)$. Rainfall, snowmelt, and periods of relative dryness produced similar responses in both watersheds. The strength of the paired watershed relation in the pre-implementation period served as confirmation to continue the project as planned. 


\section{Table 5}

Average erosion rate and Wisconsin Phosphorus Index (WPI) in baseline period (2007 to 2010) and post-implementation (2013 to 2016) for agricultural land in the treatment watershed.

\begin{tabular}{|c|c|c|c|c|c|c|c|c|c|}
\hline & \multirow[b]{3}{*}{ Area (ha) } & \multicolumn{4}{|c|}{ Erosion rate (RUSLE2) } & \multicolumn{4}{|c|}{ Phosphorus (WPI) } \\
\hline & & \multirow[b]{2}{*}{$\begin{array}{l}\text { Pre } \\
\left(\mathrm{Mg} \mathrm{ha}^{-1} \mathrm{y}^{-1}\right)\end{array}$} & \multirow[b]{2}{*}{$\begin{array}{l}\text { Post } \\
\left(\mathrm{Mg} \mathrm{ha}^{-1} \mathrm{y}^{-1}\right)\end{array}$} & \multicolumn{2}{|c|}{ Reduction } & \multirow[b]{2}{*}{ Pre } & \multirow[b]{2}{*}{ Post } & \multicolumn{2}{|c|}{ Reduction } \\
\hline & & & & $\%$ & $M g y^{-1}$ & & & $\%$ & $k g y^{-1}$ \\
\hline \multicolumn{10}{|l|}{ In project } \\
\hline Cropland* & 808 & 5.8 & 2.5 & 57 & 2,700 & 4.1 & 1.7 & 59 & 2,200 \\
\hline
\end{tabular}

Post-Implementation Stream Sediment and Phosphorus Event Load Changes. We compared loading from the treatment watershed to that of the control watershed to determine if there was a decrease due to the project's changes to land management. The approach compensated for the effect of weather and regional trends. For example, a dry year would reduce loads in both watersheds, while the concentrated effort to change land management practices would only change loading from the treatment watershed. Suspended sediment event loads decreased by $52 \%$ for events during unfrozen soil conditions $(p=0.047)$. In contrast, SS loads did not drop during frozen soil rain-onsnow and snowmelt events. Due to the lack of change when soils were frozen, year-round SS event loads did not significantly decrease $(p=0.15)$ (figure $5 \mathrm{a}$ and $5 \mathrm{~b}$; table 6). A statistically significant decrease in TP event loads followed conservation implementation in the treatment watershed $(p=0.033$ ) (figure $5 c$; table 6 ). The $50 \%$ decrease occurred across the full range of event sizes during frozen and nonfrozen soil conditions, as evidenced by relatively parallel slopes (figure $5 \mathrm{c}$ ), indicating implementation of practices had a similar effect on TP load across varying streamflow.

These results indicate that conservation practices implemented in the treatment watershed significantly reduced the amount of TP export from the watershed year-round, and SS export in unfrozen soil conditions, across the range of runoff event sizes. The project's conservation efforts may not have had a significant effect on frozen period SS loads because less upland erosion occurs during frozen soil conditions. Edge-of-field monitoring in Wisconsin has shown that SS concentrations in runoff in snowmelt events or rain on frozen soil are higher than in rainfall runoff from nonfrozen soil (Stuntebeck et al. 2011). During frozen conditions, a higher proportion of the SS in the stream is likely to have originated from bank and channel sediments than in the nonfrozen period. Lamba et al. (2015b) found that the highest proportion of sediment originating from the streambank compared to agricultural uplands in their sediment fingerprinting study came during a snowmelt event, and they postulated this may be due to bank erosion induced by freeze-thaw cycles.

Post-Implementation Stream Sediment and Phosphorus Concentrations. Comparison of in-stream low-flow $\mathrm{P}$ concentrations with those in the control watershed indicates some statistically significant post-implementation $\mathrm{P}$ reductions. While ANCOVA of low-flow SS sample concentrations did not show a statistically discernable difference, TP, TDP, and PP low-flow concentrations all decreased at the $90 \%$ confidence level $(p=0.01,0.05$, and 0.08 , respectively; table 7 ).

The reduction in low-flow PP concentrations without a similar reduction in SS concentrations indicates that the $\mathrm{P}$ concentration of SS was less in the treatment watershed during the post-implementation period compared to that of the control watershed.This may be because less erosion of soils in the treatment watershed occurred in areas with comparably high soil P. The project focused on controlling erosion in areas with high WPI values, which were often also areas with high soil $\mathrm{P}$ concentrations and/or high rates of manure $\mathrm{P}$ additions. The project also reduced barnyard runoff and direct stream deposition of fecal $\mathrm{P}$, sources that may not be associated with soil erosion. In addition, the removal of land from CRP may have increased erosion of soils with low $\mathrm{P}$ concentrations. For this project, we sampled 160 ha $(400 \mathrm{ac})$ of CRP fields and found mean
STP to be $25 \mathrm{mg} \mathrm{kg}^{-1}$ (ppm), less than the 41 $\mathrm{mg} \mathrm{kg}^{-1}$ for cropland and pasture (table 3 ).

Comparing Measured to Modeled Reductions. It may be a source of confusion that post-implementation measured event $\mathrm{P}$ load reductions were 50\% while WPI reductions across the watershed were only $18 \%$ (table 5). These results come from entirely different comparisons. The $18 \%$ reduction in WPI from cropland and pasture management is from a comparison with 2007 to 2010 management conditions. In contrast, the 50\% reduction in the treatment watershed was calculated through comparison with 2013 to 2016 loads in the control watershed. If the project had never happened, the relationship with the control would be expected not to change, but the water quality in both watersheds is likely to have become worse due to regional land management trends. As noted previously, 340 ha $(840 \mathrm{ac})$ of grasslands was converted to cropland from 2007 to 2013 , leading to an increase in erosion and runoff sediment losses. A similar conversion happened in the control watershed. Examination of 2008, 2009, and 2013 aerial imagery from the National Agriculture Imagery Program (NAIP) indicates an increase in cropland area of $15 \%$ in the control watershed, although this appears to have come primarily from conversion of pastures rather than grasslands as in the treatment watershed. There was also a similar decline in the number of animal units in the control watershed (J. McCaulley, Iowa County, personal communication, 2015).

\section{Summary and Conclusions}

The results of this study confirm that the use of the two-scale focused conservation strategy, which includes selecting a watershed likely to show a water quality response and identifying and focusing conservation practices on the highest contributing 
Figure 4

Treatment and control watershed annual (a) streamflow and precipitation, (b) suspended sediment loads by baseflow and stormflow, and (c) total phosphorus (P) loads by baseflow and stormflow for water years (October to September) 2007 through 2016.

(a)

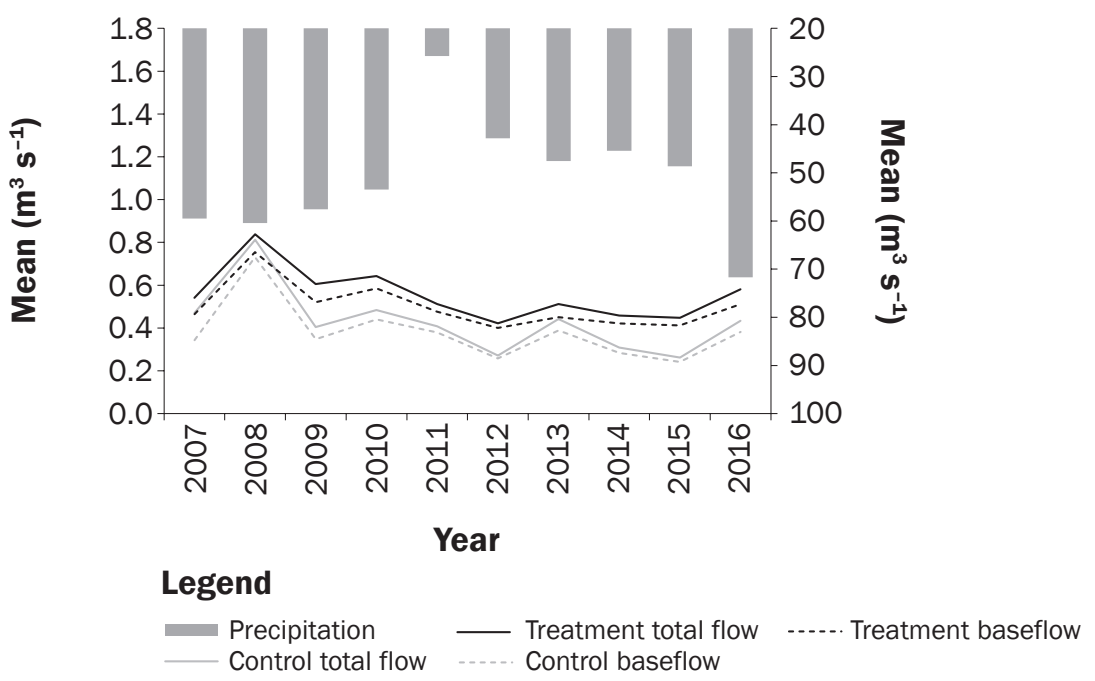

(b)

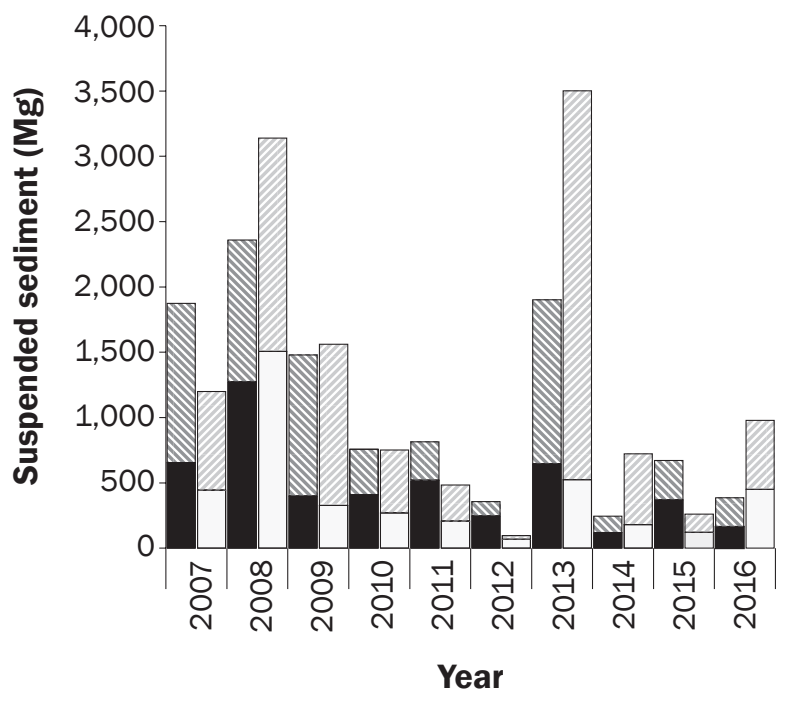

(c)

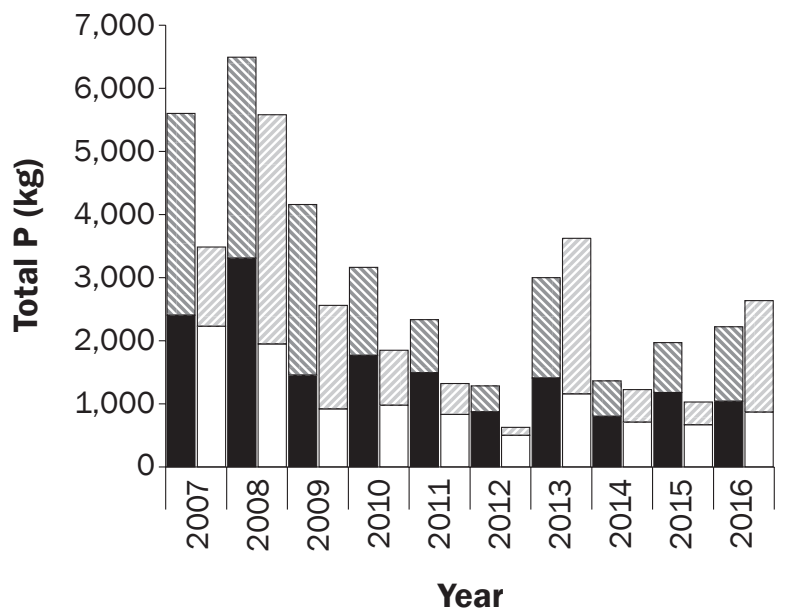

\section{Legend}

$\mathbb{N}$ Treatment event

- Treatment baseflow

$\square$ Control event

$\square$ Control baseflow

\section{Legend}

$\mathbb{N}$ Treatment event

- Treatment baseflow

$\square$ Control event

$\square$ Control baseflow areas within the watershed, is an effective approach for documenting conservation practice effectiveness. By focusing on farms with high-contributing areas identified using the WPI and other assessment methods, this project achieved significant reductions in runoff event stream P loading and lowflow P concentrations. Farmers improved stream water quality by making changes that reduced their farms' estimated $\mathrm{P}$ losses and also fit within their operations and goals.

The study also demonstrates some of the challenges with the focused conservation strategy. One of these is the time and resources required to identify and sample the high-contributing areas. In this case, the Dane County LCD staff was able to implement a focused strategy at the field level because the watershed land management inventory was in hand when funding became available for implementation incentives. Another challenge is localizing conservation efforts to specific fields when these areas are managed under an integrated system with a whole farm operation. Shifts in land operation and cropping pattern in the project demonstrated the need for periodic reassessment to identify new high-contributing areas. Without the control watershed for comparison, the impact of management practices might have been obscured by the conversion of grassland to cropland that occurred in both watersheds. Though we were not able to find previous projects documenting significant reductions in P loads and concentrations within the first years after implementation for a similarly sized watershed, a number of smaller-scale projects have done so successfully using a similar paired watershed approach (McDowell et al. 2014; Li et al. 2011; Liu et al. 2014; Bishop et al. 2005).

Using the control watershed for comparison, we were able to detect statistically significant $\mathrm{P}$ reductions in the treatment watershed in the post-implementation years. This project demonstrates that using an approach that quantifies the potential sources of runoff $\mathrm{P}$ and focuses on contributing areas can achieve sufficient farmer participation and be successful in improving stream water quality.

\section{Acknowledgements}

The authors wish to thank Pat Sutter and Duane Wagner (county conservationist and conservation specialist, respectively, Dane County Land Conservation Division, Wisconsin), and Terry Kelly and Adam Dowling (district 


\section{Figure 5}

Runoff event loads for the treatment and control watersheds during baseline (2006 to 2010) and post-implementation (2013 to 2016) for (a) suspended sediment; (b) suspended sediment, unfrozen soil conditions; and (c) total phosphorus (P). (a)

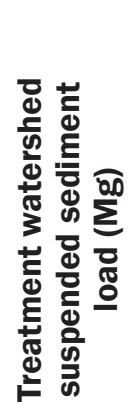

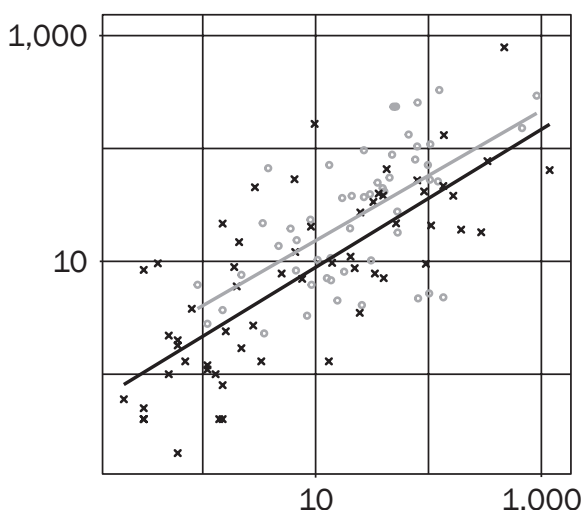

Control watershed suspended sediment load (Mg)

(b)

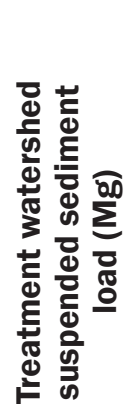

\section{1,000}

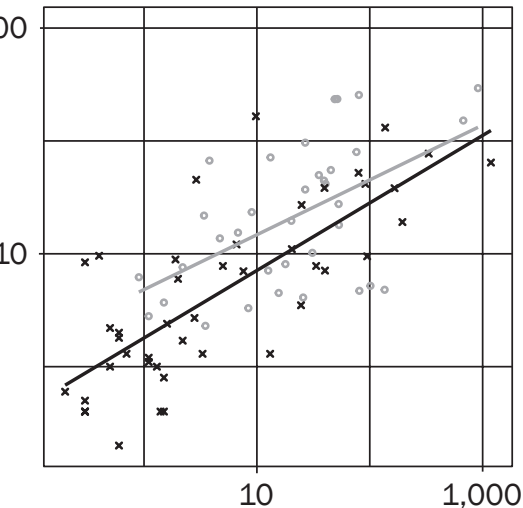

Control watershed suspended
sediment load (Mg) (c)

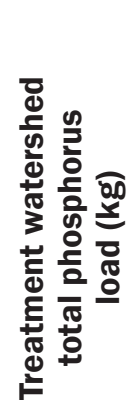

\section{1,000}

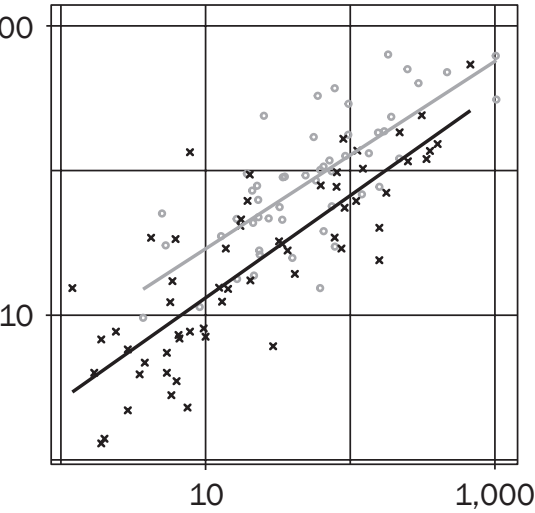
$R^{2}=0.27$

Post-implementation: $y=$

$R^{2}=0.57$
Baseline: $y=0.58 x+0.61$ $R^{2}=0.37$

Post-implementation: $y=$

$0.61 x+0.34$

$R^{2}=0.57$

\section{Legend}

* Calibration

* Post-treatment
Baseline: $y=0.48 x+0.68$

$0.60 x+0.25$

\section{Legend}

- Calibration

* Post-treatment

conservationists, USDA Natural Resources Conservation Service [NRCS] Dane County, Wisconsin) for their substantial contributions to project implementation; Rachel Eder for inventory assistance; and Matt Diebel (water resources management specialist, Department of Natural Resources, Madison, Wisconsin), Jeff Maxted (research specialist, Center for Limnology, University of Wisconsin, Madison, Wisconsin), and Pete Nowak (Wisconsin Buffer Initiative Chair, University of Wisconsin, Madison, Wisconsin) for getting the project started. We are also grateful to the USDA National Integrated Water Quality Program (Award 200951130-06049) for research funds and USDA NRCS for Cooperative Conservation Partnership Initiative (CCPI) incentive payment funds. The Nature Conservancy, with financial support from the Monsanto Company and The McKnight Foundation, supported all aspects of the project.

\section{Disclaimer}

Any use of trade, firm, or product names is for descriptive purposes only and does not imply endorsement by the US Government.

\section{References}

Aschmann, S. 2000. A reflection on the Johnson Creek Watershed Water Quality Improvement Project 19821999. Washington, DC: USDA Natural Resources Conservation Service Watershed Science Institute.

Bishop, P.L., W.D. Hively, J.R. Stedinger, M.R. Rafferty, J.L. Lojpersberger, and J.A. Bloomfield. 2005. Multivariate analysis of paired watershed data to evaluate agricultural best management practice effects on stream water phosphorus. Journal of Environmental Quality 34:1087-1101.

Carvin, R.B. 2018. Paired watershed data for Pleasant Valley Creek and Ridgeway Branch, Wisconsin 20062016. US Geological Survey data release, https:// doi.org/10.5066/F7BZ64H1. Washington, DC: US Geological Survey.

Clausen, J.C., and J. Spooner. 1993. Paired watershed study design. EPA-841-F-93-009. Washington, DC: US Environmental Protection Agency, Office of Water.

Corsi, S.R., J.F. Walker, L. Wang, J.A. Horwatich, and R.T. Bannerman. 2005. Effects of best-management practices in Otter Creek in the Sheboygan River Priority Watershed, Wisconsin, 1990-2002. USGS Report No. 2005-5009. Reston,VA: US Geological Survey.

Danz, M.E., S.R. Corsi, D.J. Graczyk, and R.T. Bannerman. 2010. Characterization of suspended solids and total phosphorus loadings from small watersheds in Wisconsin. US Geological Survey Scientific Investigations Report 2010-5039. Reston,VA: US Geological Survey.

\section{Legend}

- Calibration

* Post-treatment

Diebel, M.W., J.T. Maxted, P.J. Nowak, and M.J. Vander Zanden. 2008. Landscape planning for agricultural

\section{Control watershed total phosphorus load (kg)}

nonpoint source pollution reduction I: A geographical allocation framework. Environmental Management 42:789-802.

Diebel, M.W., J.T. Maxted, D.M. Robertson, S. Han, and M.J. Vander Zanden. 2009. Landscape planning for 
Table 6

ANCOVA results for event loads.

\begin{tabular}{|c|c|c|c|c|}
\hline \multirow[b]{2}{*}{ Source } & \multicolumn{2}{|l|}{ Suspended sediment } & \multicolumn{2}{|l|}{ Total phosphorus } \\
\hline & All year & Nonfrozen & All year & Nonfrozen \\
\hline Intercept & $0.607 * * *(0.166)$ & $0.683 * * *(0.190)$ & $0.811 * * *(0.161)$ & $0.879 * * *(0.187)$ \\
\hline Change in intercept & $-0.272(0.187)$ & $-0.429 *(0.212)$ & $-0.398 *(0.185)$ & $-0.515 *(0.213)$ \\
\hline Change in slope & $0.035(0.128)$ & $0.112(0.151)$ & $0.059(0.107)$ & $0.118(0.127)$ \\
\hline$R^{2}$ & 0.577 & 0.575 & 0.720 & 0.731 \\
\hline Observed values $(n)$ & 111 & 79 & 111 & 79 \\
\hline Predicted (Mg or kg)† & 17 & 14 & 62 & 55 \\
\hline Observed (Mg or kg)† & 10 & 6.7 & 31 & 25 \\
\hline
\end{tabular}

Notes: $\mathrm{ns}=\mathrm{a}$ nonsignificant result. Regression coefficients are log-transformed to meet the assumptions for the ANCOVA. Coefficients are reported with standard errors in parentheses. *, **, and $* * *$ indicate significance at $\alpha=0.05,0.01$, and 0.001 , respectively.

†Predicted and observed values are in Mg and kg for suspended sediment (SS) and total phosphorus (TP), respectively.

\section{Table 7}

ANCOVA results for low-flow sample concentrations.

\begin{tabular}{lllll}
\hline Source & SS & TP & TDP & PP \\
\hline Intercept & $1.108 * * *(0.268)$ & $-0.293 *(0.122)$ & $-0.012(0.168)$ & $-1.201 * * *(0.346)$ \\
Slope & $0.671 * * *(0.082)$ & $0.831 * * *(0.050)$ & $0.957 * * *(0.053)$ & $0.617 * * *(0.104)$ \\
Change in intercept & $0.168(0.530)$ & $-1.810 * * *(0.475)$ & $-2.072 * *(0.675)$ & $-1.269 \dagger(0.723)$ \\
Change in slope & $-0.162(0.193)$ & $-0.572 * *(0.181)$ & $-0.562 * *(0.205)$ & $-0.275(0.206)$ \\
\hline F-statistic & $27.7 * * *$ & $109.6 * * *$ & $123.1 * * *$ & $16.58 * * *$ \\
df & 3 and 104 & 3 and 104 & 3 and 88 & 3 and 88 \\
$R^{2}$ & 0.444 & 0.760 & 0.808 & 0.356 \\
Observed values $(n)$ & 108 & 108 & 92 & 92 \\
\hline
\end{tabular}

Notes: Regression coefficients are log-transformed to meet the assumptions for the ANCOVA. Coefficients are reported with standard errors in parentheses. $\dagger, *, * *$, and $* * *$ indicate significance at $\alpha=0.1,0.05,0.01$, and 0.001 , respectively. SS $=$ suspended sediment. TP $=$ total phosphorus. TDP $=$ total dissolved phosphorus. $\mathrm{PP}=$ particulate phosphorus.

agricultural non-point source pollution reduction III: Assessing phosphorus and sediment reduction potential. Environmental Management 43:69-83.

Dubrovsky, N.M., K.R. Burow, G.M. Clark,J.M.P.A. Gronberg, K.J. Hamilton, D.K. Hitt, M.D. Mueller, B.T. Munn, L.J. Nolan, L.J. Puckett, M.G. Rupert, T.M. Short, N.E. Spahr, I.A. Sprague, and W.G. Wilber. 2010. The quality of our Nation's waters: Nutrients in the Nation's streams and groundwater, 1992-2004. US Geological Survey Circular 1350. Washington, DC: US Geological Survey.

Fitzpatrick, F.A., J.C. Knox, and H.E. Whitman. 1999. Effects of historical land-cover changes on flooding and sedimentation, North Fish Creek, Wisconsin. US Geological Survey Water Resources Investigations Report 99-4083. Reston,VA: US Geological Survey.

Gellis, A.C., G.B. Noe, J.W. Clune, M.K. Myers, C.R. Hupp, E.R. Schenk, and G.E. Schwarz. 2015. Sources of finegrained sediment in the Linganore Creek watershed, Frederick and Carroll Counties, Maryland, 2008-10.
US Geological Survey Scientific Investigations Report 2014-5147. Reston,VA: US Geological Survey.

Good, L.W., P.A. Vadas, J.C. Panuska, C.A. Bonilla, and W.E. Jokela. 2012. Testing the Wisconsin P Index with year-round, field-scale runoff monitoring. Journal of Environmental Quality 41:1730-1740.

James, E., P. Kleinman, T.Veith, R. Stedman, and A. Sharpley. 2007. Phosphorous contributions from pastured dairy cattle to streams of the Cannonsville Watershed, New York. Journal of Soil and Water Conservation 62(1):40-47.

Kaarakka, P., L.W. Good, and J. Wolter. 2011. SNAP-Plus 1.132.8. Madison,WI: University of Wisconsin-Madison. http://snapplus.wisc.edu/downloads/14-0.

Koltun, G.F., M. Eberle, J.R. Gray, and G.D. Glysson. 2006. User's manual for the Graphical Constituent Loading Analysis System (GCLAS), US Geological Survey Techniques and Methods, 4-C1. http://water.usgs.gov/ software/GCLAS/.
Laboski, C.A.M., and J. Peters. 2012. Nutrient application guidelines for field, vegetable, and fruit crops in Wisconsin. UW-Extension Publication A2809. Madison, WI: University of Wisconsin-Extension.

Lamba, J., K.G. Karthikeyan, and A.M. Thompson. 2015b. Apportionment of suspended sediment sources in an agricultural watershed using sediment fingerprinting. Geoderma 239-240:25-33.

Lamba, J., A.M. Thompson, K.G. Karthikeyan, and F.A. Fitzpatrick. 2015a. Sources of fine sediment stored in agricultural lowland streams, Midwest, USA. Geomorphology 236:44-53.

Lemke,A.M., K.G. Kirkham,T.T. Lindenbaum, M.E. Herbert, T.H.Tear, W.L. Perry, and J.R. Herkert. 2011. Evaluating agricultural best management practices in tile-drained subwatersheds of the Mackinaw River, Illinois. Journal of Environmental Quality 40:1215-1228.

Li, S., J.A. Elliot, K.H.D. Tiessen, J. Yarotski, D.A. Lobb, and D.N. Flaten. 2011. The effects of multiple beneficial 
management practices on hydrology and nutrient losses in a small watershed in the Canadian prairies. Journal of Environmental Quality 40:1627-1642.

Lui, K., J.A. Elliot, D.A. Lobb, D.N. Flaten, and J.Yarobi. 2014. Conversion of conservation tillage to rotational tillage to reduce phosphorus losses during snowmelt runoff in the Canadian Prairies. Journal of Environmental Quality 43:1679-1689.

Maxted, J.T., M.W. Diebel, and M.J. Vander Zanden. 2009 Landscape planning for agricultural non-point source pollution reduction. II. Balancing watershed size, number of watersheds, and implementation effort. Environmental Management 43:60-68.

McDowell, R.W., G.P. Cosgrove, T. Orchiston, and J. Chrystal. 2014. A cost-effective management practice to decrease phosphorus loss from dairy farms. Journal of Environmental Quality 43:2044-2052.

Mississippi River/Gulf of Mexico Watershed Nutrient Task Force. 2008. Gulf Hypoxia Action Plan 2008 for Reducing, Mitigating, and Controlling Hypoxia in the Northern Gulf of Mexico and Improving Water Quality in the Mississippi River Basin. Washington, DC: Mississippi River Gulf of Mexico Watershed Nutrient Task Force. https://www.epa.gov/sites/production/ files/2015-03/documents/2008_8_28_msbasin_ ghap2008_update082608.pdf.

Mulla, D.J., A.S. Birr, N.R. Kitchen, and M.B. David. 2008. Limitations of evaluating the effectiveness of agricultural management practices at reducing nutrient losses to surface waters. In Final Report: Gulf Hypoxia and Local Water Quality Concerns Workshop, 189-212. St. Joseph, MI: American Society of Agricultural and Biological Engineers.

Neal, C.W.M., and A.M. Anders. 2015. Suspended sediment supply dominated by bank erosion in a low-gradient agricultural watershed, Wildcat Slough, Fisher, Illinois, United States. Journal of Soil and Water Conservation 70(3):145-155, doi:10.2489/jswc.70.3.145.

Nowak, P., S. Bowen, and P.E. Cabot. 2006. Disproportionality as a framework for linking social and biophysical systems. Society and Natural Resources 19:153-173.

Osmond, D., D. Meals, D. Hoag, M.Arabi,A. Luloff, G.Jennings, M. McFarland, J. Spooner, A. Sharpley, and D. Line. 2012. Improving conservation practices programming to protect water from agricultural watersheds: Lessons learned from the National Institute of Food and AgricultureConservation Effects Assessment Project. Journal of Soil and Water Conservation 67(5):122A-127A, doi:10.2489/ jswc.67.5.122A.

Porterfield, G. 1972. Computation of fluvial-sediment discharge. US Geological Survey Report No. 03-C3. Reston,VA: US Geological Survey.

Rantz, S.E., et al. 1982. Measurement and computation of streamflow, Volume 2-Computation of discharge. US Geological Survey Water-Supply Paper 2175. Washington, DC: US Government Printing Office.

Selbig, W.R. 2016. Evaluation of leaf removal as a means to reduce nutrient concentrations and loads in urban stormwater. Science of the Total Environment 571:124-133.

Sloto, R.A., and M.Y. Crouse. 1996. HYSEP: A computer program for streamflow hydrograph separation and analysis. US Geological Survey Water-Resources Investigations Report 96-4040. Lemoyne, PA: US Geological Survey.

Stuckey, M.H. 2006. Low-flow, base-flow, and mean-flow regression equations for Pennsylvania streams. US Geological Survey Scientific Investigations Report 2006-5130. Lemoyne, PA: US Geological Survey.

Stuntebeck, T.D., M.J. Komiskey, M.C. Peppler, D.W. Owens, and D.R. Frame. 2011. Precipitation-runoff relations and water-quality characteristics at edgeof-field stations, Discovery Farms and Pioneer Farm, Wisconsin, 2003-8. US Geological Survey Scientific Investigations Report 2011-5008. Washington, DC: US Geological Survey.

USDA ARS (Agricultural Research Service). 2006. RUSLE2. Washington, DC: USDA Agricultural Research Service. http://fargo.nserl.purdue.edu/rusle2_dataweb/ RUSLE2_Index.htm.

USDA NRCS (Natural Resources Conservation Service). 2005. Conservation Practice Standard 590. Wisconsin Field Office Technical Guide. Madison, WI: Standards Oversight Council.

USDA NRCS Wisconsin. 2005. Dominant Critical Area: Basic Planning Concepts for RUSLE2. https://www. nrcs.usda.gov/wps/portal/nrcs/detail/wi/technical/ cp/?cid=nrcs142p2_020801.

USEPA. 2008. EPA's report on the environment (ROE). EPA/600/R-07/045F. Washington, DC: US Environmental Protection Agency.

USGS (US Geological Survey). 2006. Chapter A4: Collection of water samples (ver. 2.0). In US Geological Survey Techniques of Water-Resources Investigations, Book 9. Washington, DC: US Geological Survey. http://pubs. water.usgs.gov/twri9A4/.

USGS. 2016. National Water Information System: USGS Water Data for the Nation. http://dx.doi.org/10.5066/ F7P55KJN.

UW-CALS (University of Wisconsin-Madison, College of Agricultural and Life Sciences). 2005. The Wisconsin Buffer Initiative: A report to the Natural Resources Board of the Wisconsin Department of Natural Resources. http://faculty.nelson.wisc.edu/nowak/.

WDNR (Wisconsin Department of Natural Resources). 1996. BARNY 2.6 - The Wisconsin barnyard runoff model, inventory instructions and user's manual. Madison, WI: Wisconsin Department of Natural Resources.

WDNR. 2015. Wisconsin's 2014 Impaired Waters List. Madison, WI: Wisconsin Department of Natural Resources. http://dnr.wi.gov/topic/ impairedwaters/2014IR_IWList.html.

Wis. Stats. (Wisconsin Statutes) NR 151. 2010. Runoff Management. Madison, WI: Wisconsin State Legislature. https://docs.legis.wisconsin.gov/code/admin_code/ $\mathrm{nr} / 100 / 151 / \mathrm{II} / 04$.

WSLH (Wisconsin State Laboratory of Hygiene), Environmental Sciences Section. 1993. Manual of analytical methods, inorganic chemistry unit. Madison, WI: Wisconsin State Laboratory of Hygiene.

Wolter, J., J. Beaudoin, S. Sebrosky, R. Wayne, and L.W. Good. 2016. SnapPlus v. 16.3. Madison, WI: University of Wisconsin. https://snapplus.wisc.edu/. 